\title{
Ectopia lentis et pupillae Ectopia lentis et pupillae
}

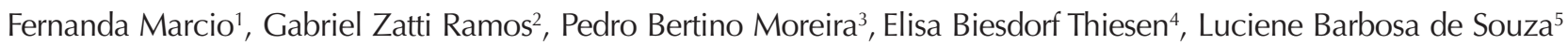

\begin{abstract}
The Ectopia lentis et pupillae is a rare genetic syndrome, congenital, autosomal recessive with variable expression, characterized by ectopia of the lens and the pupil, usually bilateral and symmetrical, but without systemic manifestations. The pathogenesis of this anomaly is still unknown, but there are theories that the change is mesodermal, neuroectodermal, combined or mechanical. This article presents a clinical case of a patient with ectopia lentis et pupillae, describing its clinical and genetic aspects, secondary ocular complications and differential diagnosis.

Keywords: Ectopia lentis; Pupillary disorders; Abnormalities of the eye; Retinal detachment; Glaucoma; Case report

\section{RESUMO}

A ectopia lentis et pupillae é uma síndrome genética rara, congênita, autossômica recessiva de expressividade variável, caracterizada por ectopia do cristalino e da pupila, geralmente bilateral e simétrica, sem associação com anormalidades sistêmicas. Sua patogênese ainda é desconhecida, porém se especula que haja alteração mesodérmica, neuroectodérmica, combinada ou mecânica. O artigo relata o caso clínico de um paciente portador de ectopia lentis et pupillae, descrevendo seus aspectos clínicos e genéticos, além de suas complicações secundárias e diagnósticos diferenciais.

Descritores: Ectopia do cristalino; Distúrbios pupilares; Anormalidades do olho; Descolamento retiniano; Glaucoma; Relato de caso
\end{abstract}

\footnotetext{
${ }^{1}$ Resident of Ophthalmology in Hospital Oftalmológico de Sorocaba - Sorocaba (SP), Brasil;

${ }^{2}$ Fellow in Retina at Hospital Oftalmológico de Sorocaba - Sorocaba (SP), Brasil;

${ }^{3}$ Fellow in Córnea at Hospital Oftalmológico de Sorocaba - Sorocaba (SP), Brasil;

${ }^{4}$ Resident of Ophthalmology at Hospital Oftalmológico de Sorocaba - Sorocaba (SP), Brasil.

${ }^{5}$ Chief of the Medical residency Program in Ophthalmology and Chief of the Cornea Departament at Hospital Oftalmológico de

Sorocaba - Sorocaba (SP), Brasil.

Institution: Department of Cataract, Hospital Oftalmológico de Sorocaba - Sorocaba (SP), Brasil.
}

Os autores declaram inexistir conflitos de interesse.

Recebido para publicação em: 20/7/2010 - Aceito para publicação em 19/3/2011 


\section{INTRODUCTION}

$\mathbf{T}$ he identification of ectopia lentis as a manifestation of a genetic syndrome or systemic disease is extremely important because the medical care of these patients, including complete ophthalmological and clinical examinations, should cover genetic counseling, in addition to diagnosis, possible complications and appropriate treatment ${ }^{(1-4)}$.

The ectopia lentis is a subluxation of the lens, which is often associated with other ocular and/or systemic findings. The early diagnosis may influence the patient, minimizing the expression of disease, such as in homocystinuria and hyperlisinemia $\mathrm{a}^{(1,2,5)}$.

The ectopia lentis et puppilae is characterized by congenital ectopia of the pupil and the lens, usually bilateral and symmetrical, although the condition can be unilateral. This anomaly limited to the eye is autosomal recessive with variable expressivity between the two eyes of the patient and family members ${ }^{(1,3,6-10)}$.

The objective of this study is to describe the case of a patient with Ectopia lentis et papillae discussing its clinical presentation, ocular complications secondary to the syndrome and differential diagnosis.

\section{Case report}

FGMV, 6 years old, male, mulatto, from Tatuí - SP, came to Hospital Oftalmológico de Sorocaba in 2007, with low visual acuity in both eyes. According to his mother, the child had ocular abnormalities since birth. Personal background: nothing important. Family history: non-consanguineous parents and healthful brothers.

Additional tests were required for exclusion of systemic disease (blood count, general biochemistry, protein eletrophoresis, urine sediment, blood homocysteine, amino acids in the blood,ECG, chest and extremities X-rays).The pediatric cardiology evaluation didn't show changes.

The examination: Visual acuity of finger count at 2 meters and at 1 meter in right and left eyes, respectively, without improvement with correction. Bilateral corneal diameters were $12 \mathrm{~mm}$. Normal keratometry and no ocular deviation.

Biomicroscopy in both eyes: iridodonesis; photoreagents oval pupils, displaced superiorly in the right and nasal superior in the left; transparent lenses displaced inferiorly and absence of iris crypts, atrophy and transillumination of the iris (Figure 1).

In both eyes, the intraocular pressure was $12 \mathrm{mmHg}$. The gonioscopy showed open angle, pectinean lines and proemient iris processes. Due to poor pupillary dilation, there was difficulty in assessing the fundus background.

The $10 \mathrm{~Hz}$ transpalpebral ultrasound revealed, in both eyes, axial diameters of $25 \mathrm{~mm}$, lower subluxation of the lenses and absence of retina detachment. The pentacam also demonstred subluxation (Figure 2).

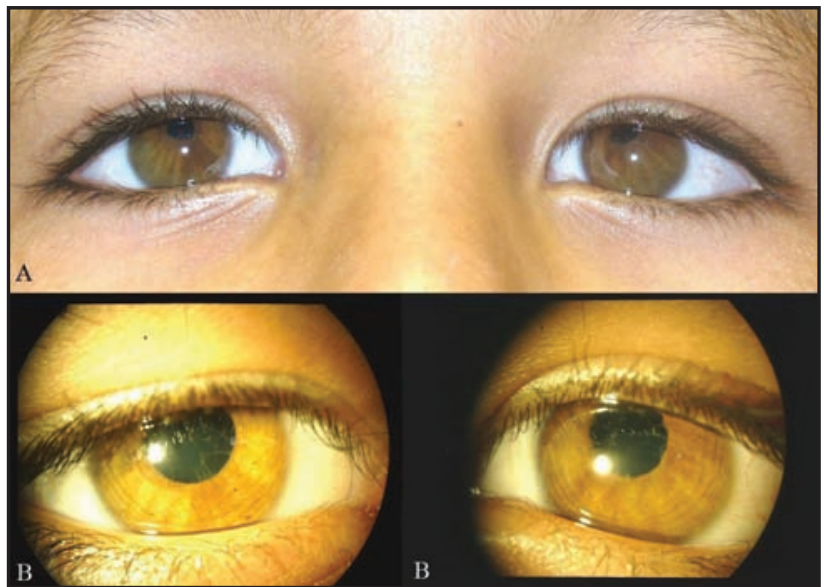

Figure 1 - A: Patient with Ectopia Lentis et Pupillae showing pupil's ectopia; B: the same with the lenses dislocated inferiorly visible when the pupils are dilated

\section{Discussion}

The ectopia lentis et pupillae is a rare congenital syndrome, autosomal recessive pattern with variable expressivity and associated with ocular abnormalities, but without systemic manifestations. Its diagnosis is mainly clinical ${ }^{(6,8-10)}$.

In ectopia lentis et pupillae, the pupils are generally discoric, slit-shaped, oval or elliptical, but in $40 \%$ of these patients are normal, with poor pupillary dilation and displaced in the opposite direction to the lens ectopia ${ }^{(3,9,10)}$. For autosomal recessive pattern, there may be consanguineous pedigree ${ }^{(1,6)}$. In our patient, as described in the literature, both the pupils have limited dilation and oval shape, superiorly displaced in the right and superior nasal in left, iridodonesis, remnants of pupillary membrane, proemients iris processes and subluxation of the lenses.

Other possible findings are: microspherophakia, transillumination of the iris in the periphery caused by the posterior pigmented layer malformation, iridodonesis, pupillary membrane persistence, proeminent iris processes, lens displacement in anterior chamber or vitreous, megalocornea, corneal astigmatism, posterior embriotoxon, strabismus and high axial myopia $^{(1,3,6-10)}$. Despite the frequent association with megalocornea, the patient studied had normal corneal diameters.

The most significant symptom is the reduction of visual acuity, depending on the displacement of the lens and the pupil,in addition to secondary complications, such as axial myopia, cataract, corneal astigmatism and retina detachment. The optical correction is not always easy, and should be done early to prevent amblyopia, where it is often necessary to associate occlusion. If the pupil position doesn't correspond to the pupillary axis can be perfomed a surgical iridectomia or the use of midriatics ${ }^{(1-3)}$. 




Figure 2 - Ultrasound (A) and pentacam (B) showed lower subluxation of the lenses in both eyes

The progressive subluxation of the lens induces frequent changes in the refractive state of the eye (myopia, astigmatism or hyperopia), distortion occurs when the equator of the lens is located in the visual axis ${ }^{(4)}$.

Surgical correction is often the only viable alternative to improve visual acuity and to prevent amblyopia. Few decades ago, the surgical treatment of subluxation of the lens was controversial because of the complications high rate and unsatisfactory visual results. Surgical studies showed that loss of vitreous and retinal detachment occurred in many patients ${ }^{(4)}$.

Nowadays ectopia of the lens has been treated with surgery but the moment of the correct indication and technique to be used varies. In children, the main factor to be considered is the amblyopia. If it can not be treated with glasses or contact lenses, surgery is the best option ${ }^{(4)}$.

The onset of cataract in subdislocated crystal is common (usually before 40 years old), and extraction usually brings complications. Surgery has to be performed when there are specific indications, such as the presence of anterior chamber lens, hypermature cataract, uveitis induced by lens, complete lens dislocation, imminent failure of the refractive optical correction or manipulation of the iris ${ }^{(1)}$.

Glaucoma and retinal detachment are common in these patients, especially after the surgical procedure and the complications are difficult to control ${ }^{(1,8,9)}$.

Differential diagnosis of ectopia lentis et pupillae are: congenital simple ectopia lentis, ectopia lentis as part of hereditary systemic diseases (S. Marfan, S. WeillMarchesan, homocystinuria, hyperlisinemia, etc), ectopia lentis associated with other ocular abnormalities (S. Rieger, aniridia, congenital glaucoma, retinitis pigmentosa), ectopia lentis of traumatic etiology and simple ectopia pupillae. Except for the last, in none of these entities concomitant pupil displacement is described $^{(1,5,9,10)}$.

The pathogenesis of this anomaly is still unknown. There are theories that the change is mesodermal, neuroectodermal, combined or mechanical ${ }^{(1,3,5-8)}$. In the latter, a persistent and abnormal vascularized tissue anastomosis with the anterolateral region of the hyaloid system near the edge of the optic cup result in traction. Consequently: pupil ectopia, malformation of zonula and instability in the corresponding area of the lens $s^{(1,6,9)}$. Moreover, the persistence of fibrovascular elements result in remnants of pupillary membrane and irido hyaloid adhesions ${ }^{(6)}$.

The correct diagnosis of Ectopia lentis et pupillae is crucial for risk assessment, prognosis and treatment, as well as the differential diagnosis with other pathologies in which there is systemic involvement ${ }^{(3)}$.

Patients with this syndrome should be clinically monitored and warned about signs and symptoms of possible complications and instructed to avoid eye injuries, participation in contact sports and physical maneuvers that may cause increased intraocular pressure $^{(1,2)}$.

\section{ReferenCes}

1. Tartarella MB, Araújo Filho A, Sallum JMF, Erwenne CM. Ectopia Lentis et Pupillae. Arq Bras Oftalmol. 1994;57(1):30-3.

2. Byles DB, Nischal KK, Cheng H. Ectopia lentis et pupillae. A hypothesis revisited. Ophthalmology. 1998;105(7):1331-6.

3. Goldberg MF. Clinical manifestations of ectopia lentis et pupillae in 16 patients. Ophthalmology. 1988;95(8):1080-7.

4. Omulecki W, Wilczynski M, Gerkowicz M. Management of bilateral ectopia lentis et pupillae syndrome. Ophthalmic Surg Lasers Imaging. 2006;37(1):68-71.

5. Luebbers JA, Goldberg MF, Herbst R, Hattenhauer J, Maumenee A E. Iris transillumination and variable expression in ectopia lentis et pupillae. Am J Ophthalmol. 1977;83(5):647-56.

6. Cross HE. Ectopia lentis et pupillae. Am J Ophthalmol. 1979;88(3 Pt 1):381-4

7. Cruysberg JR, Pinckers A. Ectopia lentis et pupillae syndrome in three generations. Br J Ophthalmol. 1995;79(2):135-8.

8. Neiva AG, Cunha RNP, Ferreira RC, Erwenne CM. Causas de cristalino ectópico em um hospital universitário. Arq Bras Oftalmol. 1995;58(5):307-9.

9. Bernardes CS, Leite LVO, Castro FAA. Ectopia lentis et pupillae: relato de caso. Arq Bras Oftalmol. 2005;68(6):841-4.

10. Oliveira DF, Marchi PH, Arieta CEL. Resultados visuais no tratamento cirúrgico da subluxação de cristalino em crianças. Medicina (Ribeirão Preto). 2002;35(1):62-9.

\section{Correspondence}

Fernanda Marcio

Rua Frederico Abranches, $n^{\circ}$ 375, apto 63

Santa Cecília

CEP 01225-001 - São Paulo - (SP), Brazil

Tel: (15) 8128-5699 / (11) 9207-9365

E-mail: fernandamarcio @ hotmail.com 